\title{
In vitro cytotoxic activity assay of bacteria extract derived marine sponge Haliclona fascigera toward Hela, WiDr, T47D, and Vero cell line
}

\author{
Neny Sandrawati ${ }^{1}$, Regina Pariatno ${ }^{2}$, Netty Suharti ${ }^{2}$, Dian Handayani ${ }^{2 *}$ \\ ${ }^{1}$ Faculty of Medicine, Andalas University, Padang, Indonesia. \\ ${ }^{2}$ Laboratory of Sumatran Biota, Faculty of Pharmacy, Andalas University, Padang, Indonesia.
}

\begin{tabular}{l}
\hline ARTICLE INFO \\
\hline Received on: 20/03/2019 \\
Accepted on: 25/06/2019 \\
Available online: 03/08/2019 \\
\hline Key words: \\
Bacillus sp., cytotoxic \\
activity, Haliclona fascigera, \\
marine-derived bacteria, \\
marine sponge.
\end{tabular}

\section{INTRODUCTION}

Cancer was one of the problems in the worldwide that need to overcome. Based on WHO statistic report (2007), about 40 million people were estimated died due to non-communicable disease (WHO, 2007). One of them leading to cancer and assumed about 8.8 million deaths (22\%) in 2015. During period 2000-2015, the mortality rate by cancer cause was stagnant.

The research and development of anticancer drugs was the largest market area in the pharmaceutical industry and over 200 anticancer compound was in a various stage in a clinical trial (Moffat et al., 2014; Xu and Wenwei, 2016). Nevertheless, some problems are still obstacles. The adverse effect, resistance in a primary and a secondary line of cancer treatment, the persistence

"Corresponding Author

Dian Handayani, Laboratory of Sumatran Biota,

Faculty of Pharmacy, Andalas University, Padang, Indonesia.

E-mail:dianhandayani@phar.unand.ac.id of cancer stem cell, and many others still limit the ability of an anticancer drug to stabilize, minimize the metastate, and cure the cancer disease (Widmer et al., 2014). In the discovery of lead compound of the anticancer drug, the small amount of compound, a minimum effect to a cancer cell in vivo, long term in clinical trial still the most factor that faced by a researcher.

Indonesian is the big archipelago state in the world, located in the tropic region, comprised 17,000 islands with many different types of habitat led to the megadiverse fauna and flora (Bruyn et al., 2014; Lohman et al., 2011). The marine sponge was available in abundance amount. Haliclona fascigera sponge that grows in West Sumatra Indonesia had been known as a potential source for various extraordinary activity (Handayani et al., 2015a; 2015b; 2016a; 2016b; 2018).

The sponge was a host for growing many symbiotic microorganisms. Association between endophyte microbe with the host could be as symbiotic mutualism until pathogenic relation (Strobel and Daisy, 2003). The different microbe can be feed sources, pathogen/parasite, or mutualism symbiotic for sponge otherwise bacteria have the essential contribution 
toward the self-defense of host by secreting antibiotic and other bioactive substances. Especially, a sessile marine organism, such sponge, was expected to have a tight connection to host defenses mechanism by producing a bioactive compound to protect from predators (Taylor et al., 2007). This fact was the fundamental reason by way of a symbiotic association between sponge and bacteria will be the promising source in exploring and finding many attractive bioactive compounds without damage the marine ecosystem on a large scale.

\section{MATERIAL AND METHODS}

\section{Sponge material}

Marine sponge sample (200 g) of $H$. fascigera was collected from Setan Island, South Coast of West Sumatra, Indonesia at depth $13 \mathrm{~m}$. The surface of the sponge was rinsed by sterile seawater and kept in icebox and then transferred to the laboratory.

\section{Isolation of marine-derived bacteria from sponge $H$. fascigera}

Isolation of symbiotic bacteria methods was conducted by the same method that had to describe previously (Handayani et al., 2015a). The rinsed sponge was cut into small pieces and wrecked down by mortar and stamper. The marine sponge was weighed as much as 10 gram and dispersed into $100 \mathrm{ml}$ sterile seawater to make serial dilution up to $10^{-6}$. One milliliter from each dilution poured to sterile Nutrient Agar (NA) medium and incubated at $37^{\circ} \mathrm{C}-38^{\circ} \mathrm{C}$ for 24 hours. The different shape and colors of colonies assumed as pure bacteria isolates and separate by scratch method into new sterile NA medium.

\section{Identification of bacteria isolate}

Symbiotic bacteria were identified by macroscopic, microscopic, and biochemical examination. Shape and color colonies in NA medium after incubated overnight and Gram staining was observed to know the group of bacteria. Some biochemical test was conducted, such as TSIA, H2S, oxidation and fermentation, catalase, nitrate, indole, Methyl Red-Voges Proskauer, carbohydrate fermentation (lactose, Glucose, sucrose, and mannitol), citrate, urease, motility, and gelatin, and result test was compared with manual book of the identification bacteria (Capuccino and Sherman, 2001; Case and Johnson, 1984).

\section{Cultivation of isolated bacteria}

The pure of bacteria derived sponge was cultivated in Nutrient Broth (NB) medium. Cultivation was started with inoculum starter. One loop of each bacterium was inoculated into $50 \mathrm{ml}$ of NB medium and incubated in an incubator shaker at $37^{\circ} \mathrm{C}$ speed $150 \mathrm{rpm}$ for 24 hours. The starter inoculum inoculated into $500 \mathrm{ml}$ of NB medium aseptically and incubation at the same temperature and speed overnight.

\section{Isolation and extraction of the secondary metabolite from bacteria isolate}

The liquid culture extracted with ethyl acetate solvent in ratio $1: 1$ for $3-5$ days by triplicate. The extract was sonicated for 10 minutes with the sonicator. Ethyl acetate fraction was separated from the medium culture using a separating funnel and filtered by
Whattmann no 2. The ethyl acetate solvent was evaporated in vacuo by rotary evaporator and obtained the dried extract of symbiotic bacteria. Each dried extract was weighed and furthermore, the weight $>50 \mathrm{mg}$ was continued to cytotoxic activity test.

\section{Screening of cytotoxic activity}

BSLT method

The Brine Shrimp Lethality Test method, shrimp nauplii Artemia salina Leach used as an indicator. Thirty milligrams from each ethyl acetate extract of symbiotic bacteria was solved in 3 $\mathrm{ml}$ ethyl acetate $\left(10^{3} \mathrm{ppm}\right)$ as a working solution. Three variations of testing concentration $(1,000,100$, and $10 \mathrm{ppm})$ were made by taken 500,50 , and $5 \mu 1$ from working solution. The dried extract of bacteria was dissolved in $50 \mu \mathrm{l}$ dimethyl sulfoxide. Ten shrimp nauplii were put in a vial that contained extract, DMSO, and sterile seawater and volume add into $5 \mathrm{ml}$ with seawater. The died nauplii were counted after 24 hours. LC $_{50}$ was calculated using the curve method by probit table. The BSLT was repeated for triplicate.

\section{MTT assay}

MTT assay was carried out with procedure experimental in Handayani et al. (2018) using symbiotic bacteria extract of marine sponge $H$. fascigera as a sample (Handayani et al., 2015a). The formula for the calculated \% viability based on MTT Assay result was:

$$
\% \text { viability }=A 1-A 0 / A 2-A 0 \times 100 \%
$$

where $A 0=$ blank absorbance

$A 1=$ absorbance of test cell + sample

$A 2=$ control absorbance $($ cell $+10 \%$ DMSO $)$

\section{Phytochemical screening}

The crude extract of symbiotic bacteria derived marine sponge $H$. fascigera were screened for the presence of terpene, steroids, alkaloids, and phenolic using the standard qualitative procedure. Anisaldehyde, concentrated sulfuric acid, dragendorff, and $\mathrm{FeCl}_{3}$ were used as the thin layer chromatography spray reagents.

\section{RESULT AND DISCUSSION}

More than 15,000 species of sponges that spread around the world have been known as a potential organism. Exploration of a bioactive compound from sponge for producing an active substance in the pharmaceutical industry mainly as an anticancer drug was a promising opportunity (Thomas et al., 2010). This condition certainly triggers the possibility of massive sponge exploitation. The exploration of microorganism that lives in sponge tissues or known as symbiont microbe was used as the best solution (Webster and Taylor, 2012).

The microbial symbionts are a microorganism that lives on the host tissue at a certain period, able to live by forming colonies on the host tissues and reach $40 \%$ of totally sponge tissue by the density of $10^{9}$ bacteria cell per mm of sponge tissue (Hoffman et al., 2005). The Mayer's study (2008) showed that symbiotic mutualism occurred between a sponge and a number of bacteria and algae, where the sponge provides support and protection for its symbionts and the symbionts provide food for 
the sponge (Mayers et al., 2014). The biochemical interaction that occurs between the sponge and the symbiotic bacteria allow the symbiotic bacteria to produce the same bioactive substance as its host. So, some types of bacteria that are symbiotic with sponges are thought to produce bioactive compounds (MearnsSpragg et al., 1998).

The purification of sponge $H$. fascigera were obtained 26 of pure isolates, nine bacteria were identified as Bacillus sp., four bacteria were Corynebacterium sp., eight bacteria were Micrococcus sp., and two other bacteria were Staphylococcus aureus based on identification result that had published before (Handayani et al., 2015a).

The amount of ethyl acetate extract on $550 \mathrm{ml}$ cultivation in NB medium was range 0.044 to $0.204 \mathrm{~g}$. Some factor such as the ability of bacteria in produce secondary metabolite was affected the extract's amount. The product ability of secondary metabolite was usually depended on a stationary phase on bacteria's growth, which the total amount of bacteria that grow and died was constant.

The screening of cytotoxic activity was only conducted toward 19 bacteria isolates which extract weight $>50 \mathrm{mg}$. The test could not be done in the least amount due to it would make a difficulty in the variation of concentration. In BSLT test using shrimp nauplii, A. salina Leach as an indicator showed that all of the ethyl acetate extracts of bacteria had $\mathrm{LC}_{50}$ value $<1,000$ ppm. One extract (code $\mathrm{H} 2 \mathrm{~N}$ ) was very cytotoxic while 18 other extracts were toxic in $\mathrm{LC}_{50}$ range 31.17 to $283.38 \mathrm{ppm}$ (Fig. 1). The concordance with Mayer (1982), the plant and animal's extract was classified toxic if it has $\mathrm{LC}_{50}$ value $30-1,000 \mathrm{ppm}$ and categorized as very toxic when $\mathrm{LC}_{50}$ value $<30 \mathrm{ppm}$ (Mayer, 1982).
In conclusion, extract with code $\mathrm{H} 2 \mathrm{~N}$ was the potential to isolate a single compound and then develop as the lead compound for an anticancer drug.

BSLT method was a preliminary test for screening cytotoxic activity. It was a simple, cost-effective, no need any material for applied and can be routinely performed to estimate the toxic effect of the extract. When we know the ability to extract toward A. salina, the extracts probably active against of cell tumor line in human.

The major advance in cytotoxic activity was MTT assay. These methods are sensitive, highly reliable, and use some human cell line. In this study, we use some cell line, i.e., Hela (cervical cancer cell), WiDr (colon adenocarcinoma), T47D (breast adenocarcinoma), and Vero (normal cell). The MTT assay was performed by a colorimetric reaction that measure viability, proliferation, and activation of the cell. In this assay was based on the converting yellow water-soluble substrate 3-(4,5-dimethylthiazol-2-yl)-2,5-diphenyl tetrazolium bromide (MTT) into a dark blue formazan product which insoluble in water and mediated by dehydrogenase enzyme in endoplasmic reticulum and mitochondria. The absorbance of the formazan purple crystals can be detected by using ELISA reader. The formation production was equal to the number of viable cells and inversely to the degree of cytotoxicity (Fotakis et al., 2006). In other words, the decrease of the \%viability cell was proportionate with increasing the cytotoxic effect.

Cytotoxic activity of the compounds can be determined by $\mathrm{IC}_{50}$ value. The determination of $\mathrm{IC}_{50}$ can be calculated by determinating of the viability percentage of a cancer cell in the

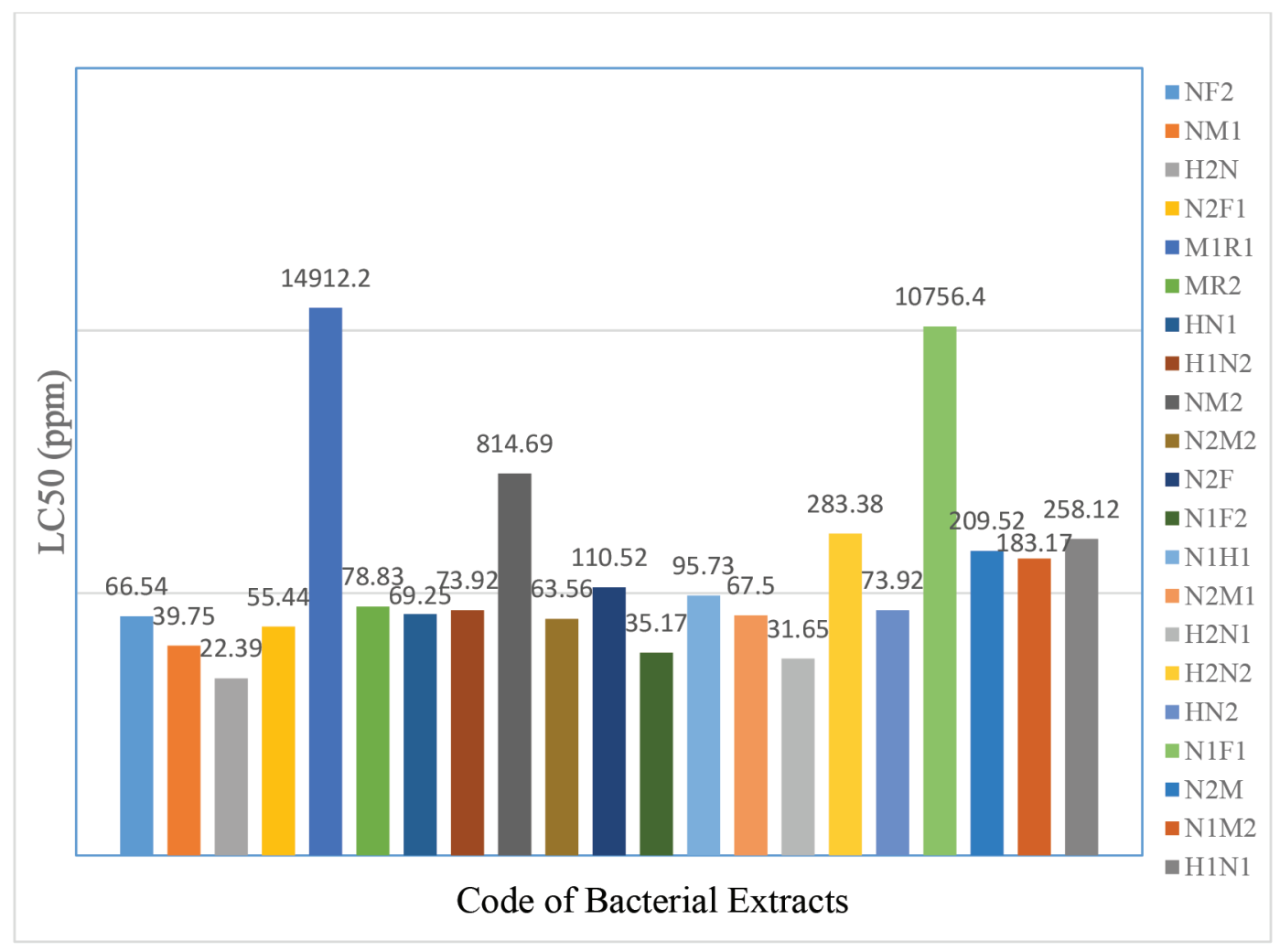

Figure 1. $\mathrm{LC}_{50}$ value of symbiotic bacteria extract from derived marine sponge Haliclona fascigera. 


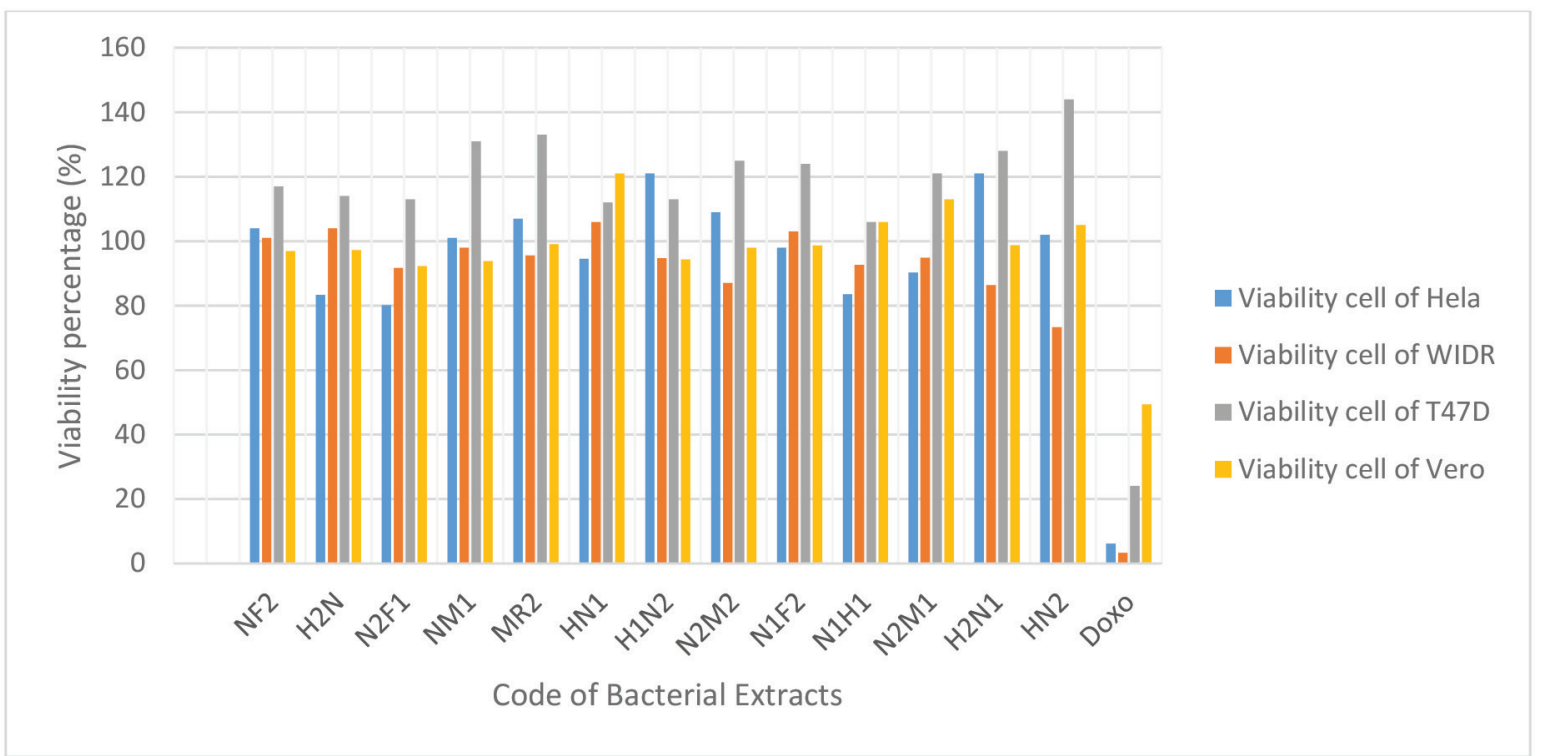

Figure 2.Viability percentage of ethyl acetate extract on the various human cancer cell line.

culture medium that contained ethyl acetate extract of symbiotic bacteria with a concentration of $100 \mu \mathrm{g} / \mathrm{ml}$ previously (Handayani et al., 2018). The percentage of viability extract is highly variable against each cancer cell; however, all of bacteria extracts did not show a good percentage of viability ( $>50 \%$ ) (Fig. 2). In MTT assay result, all of bacteria extract have no good cytotoxic activity so that determination of $\mathrm{IC}_{50}$ was carried out yet.

Bacteria extract (code $\mathrm{H} 2 \mathrm{~N}$ ) were selected to further characterization and identification. From the macroscopic and microscopic examination, also biochemical assay based on Cowan and Steel's Manual of Identification of Medical Bacterial Third Edition, it is known that the bacteria extract $\mathrm{H} 2 \mathrm{~N}$ is Bacillus sp.3.

Some previous research also stated that genus Bacillus has good bioactivity as a cytotoxic agent. Four bacteria cultures which code HA-68 (Bacillus substilis), HA MS-105 (Bacillus safensis), HA-MS-119 (Lactobacillus murinus), and HA-21 (Bacillus sp) that isolated from marine sponge Amphimedon ochracea have a cytotoxic activity to three human cancer line: HepG2 (hepatocellular carcinoma), HCT (colon carcinoma), and MCF-7 (breast carcinoma) with $\mathrm{LC}_{50}$, respectively, HA-68: 10.42, 4.3, 5.5; HA-MS-105: 46.9, 28.6, 21.3; HA-MS-119: 10.42, 6.3, and 22.1; and HA-21: 13.2, 9.3, 12.2 ppm (AboulEla, 2012). Bacillus sp. was also a potential source for isolating cytotoxic compound. Zhang et al. (2014) were succeeded to isolate three new cyclic acylpeptide, i.e., Mixirin A, B, and C from the fermentation of ethyl acetate extract of Bacillus sp. This compound has a cytotoxic effect against human intestinal tumor cell (HCT-116) with $\mathrm{LC}_{50}$ value: $0.68,1.6$, and $1.3 \mathrm{ppm}$, respectively (Zhang et al.-2004).

In this research, there is no correlation between BSLT and MTT's result. It may be due to the cytotoxic activity of bacteria extract are selective to other human cancer cell line. Therefore, this bacteria extracts can be tested to another cell line to obtain cytotoxic compound. Phytochemical screening of bacteria extract (code $\mathrm{H} 2 \mathrm{~N}$ ) suggested the presence of terpene group.

\section{CONCLUSION}

Twenty-six bacteria extracts isolated derived from marine sponge $H$. fascigera that report on Handayani et al. (2015) was tested for their cytotoxic activity. Bacillus sp.3 (H2N) isolate was showed the most $\mathrm{LC}_{50}$ value in BSLT test, unfortunately do not show the good cytotoxic activity in Hela, WiDr, T47D, and Vero Cell Line.

\section{ACKNOWLEDGMENT}

A part of this research was supported by Directorate General of Higher Education Ministry of National Education, Indonesia, in a project "International Research Collaboration and Publication, No: 163/SP2H/LT/DRPM/2019.

\section{CONFLICT OF INTEREST}

The authors declare that they have no conflict of interest.

\section{REFERENCES}

Aboul-Ela HM, Mohamed AS, Nihad MA, Galila AY, Rob WMS. Isolation, cytotoxic activity and phylogenetic analysis of Bacillus $s p$. bacteria associated with the red sea sponge Amphimedon ochracea. Adv Biosci Biotechnol, 2012; 3:815-23.

Bruyn Md, Stelbrink B, Morley RJ, Hall R, Carvalho GR, Cannon $\mathrm{CH}$. Borneo and Indochina are major evolutionary hotspots for Southeast Asian biodiversity. Syst Biol, 2014; 63(6):879-901.

Capuccino GJ, Sherman N. Microbiology (a laboratory manual) The Benyamin/Cummings Publishing Company, Inc., New York, NY, 2001. Case CL, Johnson TD. Laboratory experiments in microbiology. The Benyamin / Cummings Publishing Company,Inc., New York, NY, 1984. Fotakis G, Timbrell JA. In vitro cytotoxicity assays: comparison of LDH, neu-tral red. MTT and protein assay in hepatoma cell lines following exposure to cadmium chloride. Toxicol Lett, 2006; 160:171-7.

Handayani, Ahdinur RF, Rustini R. Antimicrobial activity of endophytic fungi from marine sponge Haliclona fascigera. J App Pharm Sci, 2015b; 5(10):154-6.

Handayani D, Murniati M, Rustini R. In vitro inhibitory activity of ethyl acetate extract of symbiotic bacteria isolated from the marine sponge Haliclona fascigera against Multidrug-Resistant Organism (MDRO). J App Pharm Sci, 2016b; 6(11):218-22. 
Handayani D, Ornando R, Rustini. Antimicrobial activity screening of symbiotic fungi from marine sponge Petrosia nigrans collected from South Coast of West Sumatera, Indonesia. Int J Pharmacogn Phytochem Res, 2016a; 8(4):623-5.

Handayani D, Rasyid W, Rustini, Zainudin EN, Hertiani T. Cytotoxic activity screening of fungal extracts derived from the West Sumatran marine sponge Haliclona fascigera to several human cell line: Hela, WiDr, T47D, and Vero. J App Pharm Sci, 2018; 8(01):055-8.

Handayani D, Sandrawaty S, Murniati M, Regina R. Screening of endophytic bacteria isolated from marine sponge Haliclona fascigera for inhibition against clinical isolates of Methicillin-Resistant Staphylococcus aureus (MRSA). J App Pharm Sci, 2015a; 5(9):139-42.

Hoffmann F, Larsen O, Thiel V, Rapp HT, Pape T, Michaelis W, Reitner J. An anaerobic world in sponges. J. Geomicrobiol, 2005; 22:1-10.

Lohman DJ, Bruyn MD, Page T, Rintelen KV, Hall R, Ng PKL, Shih HTS, Carvalho GR, Rintelen TV. Biogeography of the Indo-Australian Archipelago. Annu Rev Ecol Evol Syst, 2011; 42(1):205-26.

Mayer BN, Ferrign RN, Putnam JE, Nicholas DE, McLaughlin JL. Brineshrimp: a convenient general bioassay for active plants contituents. Planta Med, 1982; 45:31-4.

Mayers, P Espinosa, Parr, CS Jones, Hammond GS, Dewey TA. The animal diversity web, 2014. [ONLINE] Available via http:// animaldiversity.org (Accessed 07 January 2014).

Mearns-Spragg A, Bregu KG, Boyd, JG Burgess. Cross-species introduction and enhancement of antimicrobial activity produced by epibiotic bacteria from marine algae and invertebrates, after exposure to terrestrial bacteria. Letter Appl Microbiol, 1998; 27:142-6.

Moffat JG, Rudolph J, Bailey D. Phenotypic screening in cancer drug discovery-past, present, and future. Nat Rev Drug Discov, 2014 13:588-602.
Strobel G, Daisy B. Bioprospecting for microbial endophytes and their natural products. Microbiol and Mol biol Rev, 2003; 67:491-502.

Taylor MW, Radax R, Steger D, Wagner M. Sponge-associated microorganism: evolution, ecology, and biotechnological potential Microbio Mol Bio Rev, 2007; 2:295-347.

Thomas TRA, Kavlekar DP, LokaBharathi PA. Marine drugs from sponge-microbe association — a review. Mar Drugs, 2010; 8(4):141-6.

Webster NS, Taylor M. Marine sponges, and their microbial symbionts: love and other relationships. Environ Microbiol, 2012; 14(2):335-46.

WHO. World Health Statistic. WHO Press, World Health Organization, Geneva, Switerland, 2007.

Widmer N, Bardin C, Chatelut E, Paci A, Beijnen J, Levêque D. Review of therapeutic drug monitoring of anticancer drugs part twotargeted therapies. Eur J Cancer, 2014; 50:2020-36.

$\mathrm{Xu} \mathrm{J}$, Wenwei M. Overview of research and development for anticancer drugs. J Cancer Ther, 2016; 7:762-72.

Zhang HL, Hua HM, Pei YH, Yao S. Three new cyclic acyl peptides from marine Bacillus sp. Chem Pharm Bull, 2004; 52:1029-30.

\section{How to cite this article:}

Sandrawati N, Pariatno R, Suharti N, Handayani D. In vitro cytotoxic activity assay of bacteria extract derived marine sponge Haliclona fascigera toward Hela, WiDr, T47D, and Vero cell line. J Appl Pharm Sci, 2019; 9(08):066-070. 